\title{
CULPA E SÁTIRA NO DIVÃ: DUAS CRÔNICAS JORNALÍSTICAS DE SAYED KASHUA
}

\author{
Juliana Portenoy Schlesinger*
}

\section{Resumo}

Neste artigo, são analisadas duas crônicas jornalísticas do escritor árabe israelense Sayed Kashua publicadas no jornal Haaretz. Nelas, um embate entre uma sociedade radical e racista e a herança ética e moral dos idealizadores do Sionismo, segundo a qual os árabes receberiam direitos iguais aos da população judaica, encontram-se como pano de fundo de histórias tão satíricas quanto trágicas. O preconceito contra o árabe permeia as situações pelas quais passa o eu do cronista, mas cabe ao leitor decidir se ele é apenas uma possibilidade que poderia ser vivenciada, se ele de fato está presente nas relações do árabe na sociedade judaico israelense à sua volta ou se estas são alternativas que se complementam.

Palavras-chave: Sayed Kashua, crônica jornalística, Haaretz, árabe israelense, preconceito, ironia

\section{Abstract}

In this paper, I analyze two journalistic chronicles written by the Israeli Arab author Sayed Kashua published in Israeli newspaper Haaretz. In these texts, a clash between a radical and racist society and the ethics and moral heritage of the creators of Zionism, according to which the Arabs would receive equal rights as the Jewish population, are the background of these stories which are

* Pós-doutoranda da Faculdade de Filosofia, Letras e Ciências Humanas da Universidade de São Paulo, bolsista da FAPESP. <juportenoy@ gmail.com>

Toda tradução de crônicas e trechos de textos e artigos presentes neste artigo foi feita pela autora e é de sua responsabilidade. 
as satirical as tragic. The prejudice against the Arab population permeates the situations in which "I of the chronicler" live, but it is up to the reader to decide if it is just a possibility that could be experienced, if they actually permeate the Arab relations in Israeli Jewish society or if these are alternatives that are complementary.

Keywords: Sayed Kashua, journalistic chronicles, Haaretz, Israeli Arab, prejudice, irony

\footnotetext{
$\mathbf{S}$
} ayed Kashua é um autor nada convencional. Sua atuação vasta e diversificada em diversos meios torna sua obra complexa. Da linguagem televisiva utilizada na série humorística Avodá Aravit (Trabalho Árabe) - que levou, pela primeira vez ao horário nobre da televisão israelense, personagens falantes do árabe, já se encontra na sua terceira temporada e venceu o prêmio de melhor série de televisão no Festival de Filmes de Jerusalém, em 2008 -, passando pela linguagem literária dos seus três romances - Aravim Rokdim (Árabes Dançantes), de 2002, Vaiehi Boker (E fez-se a manhã), de 2004 e Guf Sheni Iachid (Segunda Pessoa do Singular) ${ }^{1}$, de 2011, este vencedor do prêmio Bernstein de Literatura -, chegamos a sua coluna semanal no jornal israelense Haaretz, publicada há mais de sete anos. Suas crônicas jornalísticas, assim como a maior parte do seu trabalho, independentemente da linguagem utilizada, são reconhecidas por um uso específico de humor.

Sayed Kashua é um cidadão árabe israelense ${ }^{2}$ que nasceu em 1975 na pequena cidade árabe de Tira, na região do Triângulo (oeste da Linha Verde). Quando adolescente, deixou sua cidade natal ao ser aceito numa prestigiosa escola em Jerusalém, a Escola de Ciências e Artes, destinada a alunos com capacidades especiais, cujo idioma de instrução é o hebraico e o público ma-

\footnotetext{
Nenhum romance foi traduzido para o português.

2 Denomina-se cidadão árabe israelense aquele árabe ou falante do árabe que seja cidadão israelense não judeu. Eles representam aproximadamente $20 \%$ da população israelense total, sendo constituídos por mulçumanos ( $83 \%$ deste grupo, maioria sunita), cristãos $(8,5 \%)$ e drusos $8,3 \%$. A maior parte desta população é descendente dos aproximadamente 160 mil árabes que permaneceram em Israel depois do estabelecimento do Estado em 1948.
} 
joritário é o judaico ${ }^{3}$. Posteriormente, estudou Filosofia e Sociologia na Universidade Hebraica de Jerusalém. Kashua é uma exceção no que tange à sua origem muçulmana e ao fato de somente escrever e publicar em hebraico, ao contrário de outros autores que têm origem cristã ou drusa e escrevem tanto em hebraico quanto em árabe.

Não é em todas as crônicas de Kashua que o humor faz-se presente. Vê-se que existem épocas em que o cronista trabalha temas de teor mais político, que ficam presos à linguagem jornalística. O próprio autor reconhece que, dependendo do contexto político em que Israel se encontra, não é possível fazer uso do humor ${ }^{4}$. Há crônicas em que o humor é escancarado, mesmo que revestido por tragicomédia. Há outras que eu as considero humorísticas, embora o próprio autor não as veja desta maneira, vendo-as somente como trágicas 5 .

Neste artigo, trabalharei duas crônicas que apresentam diversas similaridades entre si. Ambas utilizam-se de um humor muito específico e refinado, foram escritas na mesma época (uma semana de diferença), e trabalham o modo como o indivíduo (no caso, o árabe-israelense "eu do cronista") vivencia e interpreta o seu contexto social e político e como ele reage a esta vivência e interpretação.

3 Desde o início do assentamento judaico sionista na Palestina e durante todo o período do mandato britânico, a área residencial e principalmente educacional foi separada entre aquelas destinadas a árabes e a judeus (GAVISON, 2000). Hoje em dia, o sistema público israelense de educação é organizado em três esferas: "judaica geral", "judaica religiosa" e "árabe”. Nos dois setores judaicos, o idioma de instrução é o hebraico, enquanto o árabe é o de instrução do setor árabe. Os três setores são governados e pedagogicamente administrados pelo Ministério da Educação israelense. As escolas públicas religiosas gozam de autonomia pedagógica. As escolas judaicas gerais ensinam o árabe como terceira língua opcional depois do inglês (ainda assim, o árabe pode ser substituído pelo francês e novos imigrantes estão desobrigados de estudar essa terceira língua). Atualmente, existem em Israel as chamadas escolas bilíngues árabe-hebraicas.

4 Em comunicação pessoal, Nova York, abril de 2012.

5 Em comunicação pessoal, Nova York, abril de 2012.

6 Simon (2011) acredita que os termos "personagem" e "narrador" não são sempre adequados para classificar os seres presentes em determinadas crônicas. Para ele, "[...] em certas crônicas, a primeira pessoa do discurso nem sempre pode ser vinculada à pessoa física do cronista ou do escritor, porque, muitas vezes o eu se abstém de narrar, optando apenas por comentar ou expor sentimentos" (p. 29). Segundo Simon (2011), "[...] este $e u$ é uma criatura do cronista, criação que se desvincula de qualquer compromisso verídico ou autobiográfico, pois se inscreve em um modelo de texto que flerta também com situações científicas" (p. 53). Assim é proposta a terminologia "eu do cronista" para desatrelar o autor das crônicas daquelas situações e emoções expostas por ele nos textos. 
A análise literária destes textos, baseada nos estudos culturais, que privilegia o destaque aos conflitos ideológico e identitário, com os quais convive o cidadão pós-moderno, reforçará a crença de importantes autores brasileiros, tais como Antonio Candido (1992) e Davi Arrigucci Jr. (1987), de que a crônica jornalística pode e deve ser lida e analisada como um texto literário.

Nestas crônicas, Sayed Kashua apresenta ao seu leitor um "eu do cronista", que vive preso a culpas e angústias, as quais refletem uma dificuldade em captar os códigos sociais daquele país. Este é o artifício literário utilizado pelo autor para mostrar que, o que aparenta ser preconceito do judeu contra o árabe, é na realidade uma ingenuidade deste personagem, que mistura e confunde sua experiência em nível coletivo em Israel com sua experiência pessoal. O cronista, que é um árabe israelense, conhece estes códigos e brinca com eles. Ele é o outro árabe israelense, diferente daquele retratado no texto. Ele manipula a forma como este cidadão vive em Israel, resultando numa experiência naquela sociedade tanto hilária, quanto trágica.

Este cronista faz uso de um humor que pressupõe o conhecimento de certos códigos próprios daquela sociedade por parte do leitor. Por este motivo, em certas passagens, a autora interpretará alguns destes marcadores da sociedade israelense. $\mathrm{O}$ conhecimento destes códigos permite uma leitura mais profunda das crônicas, que não se restrinja nem ao lado humorístico nem ao lado trágico destes textos.

Se por um lado estes textos literário-jornalísticos ${ }^{7}$ consistem na crítica às instituições israelenses, aos males da sociedade e seus indivíduos, por outro, é sua ironia que permite que o "eu do cronista" se aprofunde nos seus próprios dilemas, preconceitos e culpas ${ }^{8}$. Nestas crônicas, o indivíduo, pequeno que é, chega a conclusões totalizantes e gerais, para então retornar ao individual, com suas fraquezas e dúvidas. É um vai e vem. O indivíduo é fruto daquela socieda-

7 Simon (2011) chama atenção para as características da crônica jornalística, ao considerá-la um gênero dúbio, no qual a nomenclatura tradicional deve ser revista e os pares tradicionais crônica/conto, escritor/ jornalista, narrador/autor, ficção/não ficção, gênero/forma e livro/jornal, devem ser reinterpretados dentro de um contexto mais amplo e menos limitador de significados.

8 Oliveira $(2005,2008)$ afirma ver a crônica como um espaço narrativo tensionado entre as estratégias narrativas de um autor ficcional letrado, que conhece os modelos literários e sabe manipular o discurso e seus efeitos sobre o leitor, e a despretensão de um relato simples e espontâneo, próximo aos acontecimentos do cotidiano e capaz de criar laços com o leitor comum. Para a autora (OLIVEIRA, 2008), é sua liberdade de uso de linguagens e estilos que auxilia o autor a tratar temas difíceis. 
de, mas também a produz e a reproduz. A sociedade é fruto daquele indivíduo, mas também o produz e reproduz.

É desta forma que funcionam estas crônicas no jornal israelense Haaretz. Haaretz, ironicamente, significa $A$ Terra, em referência à terra à qual os judeus iriam retornar, Sion, Israel, Jerusalém ${ }^{9}$ Se a denominação denota a ideologia sionista $^{10}$, o jornal, considerado o mais relevante e democrático meio de comunicação de Israel, tem como política editorial a polifonia. Nele, expressam-se os mais diferentes discursos e pontos de vista. Até mesmo de Sayed Kashua, um árabe cidadão israelense que flerta com a paródia e com a sátira, ao mostrar ao seu leitor os profundos dilemas pelos quais passa o cidadão árabe israelense, seus conflitos ideológicos e partidários, identitários e humanitários.

$\mathrm{Na}$ crônica do dia 20 de janeiro de 2012, intitulada "Um país de caráter: um encontro com o demônio no supermercado numa sexta-feira 13" (Medina im of - Peguisha im hassatan bassuper - iom shishi - 13 lachodesh), Kashua introduz o texto relatando que a esposa pede para que o "eu do cronista" vá ao supermercado:

Eu sei que eu não deveria sair de casa numa manhã chuvosa como esta, principalmente não numa manhã de sexta-feira 13 [...]. Uma sensação ruim continuou enquanto eu liguei o rádio do carro para ouvir dois jornalistas discutindo a favor da nova lei para prender refugiados da África. Sim, é uma lei dura, eles concordaram, mas no mesmo fôlego eles declararam que ela era absolutamente vital 'para que o caráter da nação fosse mantido'. Eles estão certos, eu pensei. Este país sempre teve um caráter definido e nós não podemos brincar com isto agora, que a nação perca seu senso próprio, Deus proíba, e se torne crítica e igualitária da noite para o dia. Afinal de contas, sem um caráter

9 O termo bíblico Sion designa a cidade de Jerusalém e a terra prometida por Deus aos israelitas segundo a narrativa bíblica.

10 A ideologia sionista relaciona-se ao movimento nacionalista judaico que apoia a existência de um Estado judeu em Israel. Organizado formalmente no século XIX, o movimento foi bem-sucedido ao estabelecer o Estado de Israel, em 1948, como o primeiro e único Estado judeu do mundo dos tempos modernos. 
definido, será difícil para a nação aprovar leis que previnam a união das famílias daqueles cidadãos que não nasceram de nacionalidade ou religião preferidas.

Aqui, o "eu do cronista" faz uma crítica à nação da qual faz parte e a crônica flerta decisivamente com o jornalismo, na referência direta que o cronista faz às últimas manchetes israelenses. $\mathrm{O}$ debate acerca da expulsão de imigrantes ilegais provindos do Sudão estava em foco nas notícias ${ }^{11}$. A ironia presente neste trecho é compreensível a partir do ponto de vista do "eu do cronista", um árabe israelense que, em diversos momentos da história de Israel, viu seu status como cidadão daquele país questionado ${ }^{12}$.

Até este ponto, a crônica manteve-se atrelada à sua natureza dúbia, algo entre o jornalismo e a ficção. A partir de agora, a leitura de um texto que flui como literatura se inicia. O país-nação, grande, poderoso, supraindividual, que dita regras, que tem códigos pré-estabelecidos, dá lugar ao seu cidadão, que carrega mágoas, que é produto desta sociedade que o engole, o sacrifica e determina o seu futuro. Mas, ao mesmo tempo, este mesmo indivíduo vem carregado de culpas, falhas e visões distorcidas do outro e de si próprio, das regras sociais e de seus códigos, fatos que constroem uma sociedade particular, privada, única. Este indivíduo, nesta crônica de Kashua, está deitado no divã. É ele, diante de seus "pais", de sua história pessoal, de seus conflitos mais internos e íntimos, e não mais frente ao seu país. Agora, quando ele retorna às compras no

11 No início de junho de 2012, Israel deportou centenas de refugiados sudaneses para seu país de origem. O Ministro do Interior, Eli Yishai, declarou que este seria o primeiro dos diversos passos que seriam dados para que sua visão de uma Israel livre de imigrantes fosse concretizada. Acesso em: 7 ago. 2012. Disponível em: < http://www.haaretz.com/news/national/israel-begins-deportation-of-south-sudanese-migrants$1.435523>$

12 Durante as eleições para o parlamento israelense de 2009, Avigdor Lieberman e seu partido Israel Beiteinu tornaram-se parte da coalizão do governo israelense e Lieberman foi eleito ministro das Relações Exteriores do país (chanceler). Lieberman é autor do slogan "Bli Neemanut ein Ezrahut" ("Sem fidelidade, não há cidadania"), que questiona o direito dos árabes à cidadania israelense. Ele também encabeça o chamado Plano Lieberman, que apoia uma troca de terra para assegurar a continuidade da maioria judaica em Israel. Uma proposta específica sugere a transferência de parte da população da região do Triângulo para a jurisdição da Autoridade Nacional Palestina (OLP) e de um futuro Estado Palestino, em troca do controle sobre a maior parte dos blocos de assentamentos que estão construídos na Cisjordânia. 
supermercado, é a vez de deixar a noção de nação de lado e lidar com a mente humana, repleta de medos e angústias.

'Eu esperei pacientemente por um longo tempo pelo casal, tirando suas sacolas do carrinho e colocando-as no carro, para pegar sua vaga no estacionamento. Os incompetentes não se incomodaram em deixar o carrinho bem no meio da vaga. Eu vou tirar, eu decidi. Desci do carro e fui em direção a ele'. 'Desculpe-me', uma doce voz feminina me chamou e quando eu virei, vi uma bela mulher com um sorriso angelical vindo em minha direção. 'Você quer o carrinho, ou posso leválo?', ela me perguntou. 'Claro, você pode levá-lo', eu respondi um pouco enrubescido [...]. 'Fora, na entrada do supermercado, eu descobri que os carrinhos estavam todos tomados e que havia uma fila de clientes esperando carrinhos a serem devolvidos. Eu xinguei a mulher do sorriso diabólico com toda a minha força. É assim que é. As pessoas não têm mais boas maneiras. Eles são insolentes, a ponto de falar em caráter da nação.'

$\mathrm{O}$ "eu do cronista" insinua que aquela mulher que teoricamente o enganou é o reflexo daquele país ao fazer alusão ao "caráter da nação". Paira no ar a pergunta se realmente a mulher foi dissimulada ao pegar o carrinho do eu do protagonista ou se ela na realidade não sabia que não havia carrinhos disponíveis. $\mathrm{O}$ "eu do cronista" também nos dá a entender que ele sentiu-se atraído pela mulher, o que o impediu de recusar o seu pedido. Ele se deixou enganar. Além disso, ele mistura um problema que aconteceu na sua vida particular com uma problemática maior, relatada por ele como uma nação cujo caráter está manchado.

O "eu do cronista" continua contando que ele, então, teve que entrar no supermercado sem carrinho. Ele foi até um caixa pedir ajuda. A mulher puxou o microfone e chamou: 
'Walid, Walid, ajuda nos carrinhos. Agora, Walid [...]. Levou-me mais de uma hora para encontrar todos os itens da lista e toda a vez que eu tive problemas para achar um produto específico, os funcionários árabes do supermercado gentilmente me ajudavam. De tempos em tempos, um barulho era ouvido ou uma batida, $\mathrm{e}$ imediatamente o alto-falante: 'Hamdi, Hamdi, para o corredor de produtos de limpeza agora, Hamdi.'

A partir do uso de nomes árabes, o "eu do cronista" nos mostra que o lugar dos árabes na sociedade israelense é o lugar do empregado árabe no supermercado - restrito ao empacotamento e à seção da limpeza -, enquanto judeus dão ordem, fazem as regras, enganam. A nação se faz presente no supermercado no nível da relação interpessoal.

A crônica segue contando que, já no caixa, acontece um pequeno acidente e o "eu do cronista" tem suas mãos sujas por um produto de limpeza.

'Isto é cloro', uma voz familiar veio de trás de mim e eu me virei para ver o doce rosto da mulher que roubara meu carrinho anteriormente. 'Hamdi, Hamdi, para o caixa número 3, agora, Hamdi', eu ouvi o alto-falante [...]. Minhas mãos começaram a arder e a mulher atrás de mim disse-me com um sorriso malevolente: 'Você precisa lavar suas mãos rápido. É perigoso'.

Certo de que aquele era somente mais um truque da mulher do sorriso sedutor e diabólico, ele afirma:

Nunca, eu decidi. Era claro para mim que se eu deixasse meu lugar na fila, eu estaria abrindo mão de todos os meus princípios - fossem quais fossem. Eu não vou me entregar a ela, nem à ardência das minhas mãos. Ceder a pessoas como ela não vai me ajudar a chegar à política justa. 
Como a mulher poderia ter sido correta com ele num país que, segundo o cronista, pratica políticas discriminatórias? Como o cidadão pode seguir princípios éticos e morais numa realidade como esta? O sentimento de inferioridade em Israel e a alegação de perseguição discriminatória são artifícios literários utilizados pelo cronista para expor ao leitor um árabe ingênuo, que não se adapta aos padrões daquela sociedade, que não sabe que, em Israel, furar fila e pegar carrinho de supermercado de outra pessoa numa véspera de Shabat ${ }^{13}$ não tem necessariamente a ver com conflito étnico ou religioso, nem mesmo político.

Contudo, assim como todas as outras sociedades, a israelense é mais complexa do que o simples estabelecimento de regras comportamentais.

'Está bem', eu respondi tentando continuar esvaziando o carrinho, embora tenha logo percebido que se eu não quisesse passar o resto desta terrível sexta-feira no hospital, eu deveria ir lavar minhas mãos. Eu deixei que a água escorresse por um longo período, tentando aplacar a dor, antes de voltar ao caixa. Eu estava ansioso por voltar e encontrar a mulher demônio, desejando achar coragem para dar a ela o que ela merecia. Talvez eu grite com ela, [...] acusá-la-ia de interesseira e mais alguma coisa que eu estava tentando transformar em palavras - algo sobre o caráter da nação.

$\mathrm{O}$ inusitado se faz presente. Aquilo que é aparentemente óbvio resulta num grande desconhecimento do "eu do cronista" da sociedade em que habita.

'Deu 1.245 shekels', disse a caixa quando eu me aproximei. 'O que?', eu não estava entendendo sobre o que ela estava falando. 'Aquela mulher', disse a caixa,

13 A maioria dos estabelecimentos comerciais de Israel fecha na véspera do Shabat, o dia do descanso na tradição judaica. Por este motivo, supermercados estão lotados nas tardes de sexta-feira, momentos que antecedem o início do Shabat. As pessoas costumam estar com pressa e ansiosas por fazer tudo o que necessitam até que a vida comercial se reestabeleça no sábado à noite ou domingo pela manhã. 
apontando para a mulher demônio que estava atrás de mim na fila, 'empacotou todas as suas compras por você'. 'Uau, muito obrigado', eu disse para a mulher, olhando para as sacolas tão bem arrumadas no carrinho - muito mais arrumadas do que eu poderia fazer. 'Você deveria passar um hidratante em suas mãos quando chegar em casa', ela disse [...]. Eu me senti terrivelmente envergonhado. Coloquei as coisas no carro cuidadosamente. Quando acabei, olhei para o carrinho vazio, dando uma espiada para ver se ninguém estava me olhando, e o coloquei entre dois carros estacionados.

O indivíduo daquela nação, que o eu do protagonista acusa no início da crônica de agir de forma imoral, não corresponde integralmente à experiência pessoal pela qual ele passa no supermercado. A mulher, que supostamente roubou seu carrinho, poderia sim ajudá-lo no empacotamento. Isto é bem provável que aconteça em Israel. São códigos sociais que o "eu do cronista” desconhece. Como viver naquela sociedade em que seus cidadãos certas vezes o enganam e em outras são solidários? Como viver numa sociedade em que árabes são, sim, os funcionários de limpeza e organização de supermercados, enquanto judeus dão ordens e enganam, mas onde também os árabes podem ser consumidores deste mesmo supermercado e pagar contas semanais, como os 1.245 shekels (cerca de R\$ 300) pagos pelo “eu do cronista"?

Os árabes são considerados cidadãos de segunda categoria nas notícias, na organização e hierarquia de trabalho em Israel ${ }^{14}$, mas a experiência pessoal pela qual o "eu do cronista” passa é mais complexa, assim como o status destes rados pelo Estado, incluindo direito de expressão e organização política, direito ao voto e de segurança, o país privilegia a população judaica em detrimento do restante da população, por meio de um sistema legal que permite que o Estado tome decisões estratégicas visando à garantia da manutenção de seu status judaico. As consequências disso são uma enorme diferença entre as populações judaica e árabe de Israel em termos de escolaridade, status, expectativa de vida e ganhos salariais. A comunidade árabe de Israel é politicamente subdesenvolvida e está economicamente em desvantagem em relação à maioria judaica. 
cidadãos em seu país. Avineri (2012) chama atenção para a complexidade da questão que envolve os árabes israelenses. Segundo ele, o ideólogo do sionismo político, Herzl ${ }^{15}$, vislumbrava o estabelecimento de Israel, ainda no final do século XIX e início do século XX, onde a população árabe local recebesse não apenas direitos políticos iguais aos da população judaica, mas também total acesso a políticas sociais e econômicas, o que corresponderia a um credo moral e político daquele país a ser fundado. Mas Avineri (2012) reconhece:

Recentemente, o desenvolvimento político (de Israel) lançou uma armadilha sobre este legado (de Herzl). (Ela consiste em) algumas propostas legislativas provenientes de alguns dos partidos de direita do Knesset (parlamento israelense). Embora a maioria destes projetos de lei detestáveis e racistas não seja aprovada pelo Knesset ou seja anulada pela Suprema Corte de Justiça, alguns têm sido adotados, e o fato de que outros foram debatidos pela sociedade israelense tem um efeito nocivo no clima político e moral do país [...]. Estes passos não são apenas antidemocráticos; eles também são antissionistas e minam a visão de Israel como um Estado-nação judaico membro da família das nações. [...] Israel precisa ser fiel ao seu legado. ${ }^{16}$

Apesar deste contexto sombrio, o sociólogo Sammy Smooha (1989, 1992, 1997) defende que os árabes cidadãos de Israel integram-se à sociedade israelense e ao seu sistema num crescendo e que eles adotaram estratégias para lidar com a sociedade israelense que incluem atuar dentro da sua estrutura legal para lutar pela igualdade e mudança de status. Do lado do governo israelense, notase nos últimos anos um aumento no número de estudantes de origem árabe nas universidades hebraicas e atitudes positivas, como o sistema de cotas, que vi-

15 Theodor Herzl (Budapeste, 1860-Edlach, 1904) é conhecido como o pai do sionismo político, movimento nacional que visava a estabelecer uma pátria judaica que resolveria o problema de perseguição que os judeus enfrentavam na Europa Oriental no final do século XIX e começo do século XX.

16 Acesso em: 20 ago. 2012. Disponível em: <http://www.jewishreviewofbooks.com/publications/detail/ rereading-herzls-old-new-land> 
sam ao acesso destes cidadãos a postos de trabalho majoritariamente judaicos.

Este embate entre uma sociedade radical e racista e a herança ética e moral dos idealizadores do sionismo está presente no dia a dia daquela sociedade, assim como nesta crônica de Kashua. Se por um lado o árabe é o funcionário de limpeza, por outro, ele é o consumidor deste mesmo supermercado. E a mulher que aparentemente o engana no início da crônica, não necessariamente o faz por preconceito e finalmente mostra um lado solidário que não corresponde a uma total falta de caráter. O lado ingênuo, inseguro e vulnerável do "eu do cronista" mostra-nos uma faceta que se aproxima mais da Israel da notícia do rádio, a Israel dos extremistas, daqueles que distanciam o país daquele legado de justiça. Mas isto é exposto de uma maneira muito peculiar. Longe do olhar que busca a neutralidade e a discrição, esta crônica de Kashua flerta mais com a paródia e com a autoironia, e o efeito por elas provocado é tanto de crítica social quanto de divertimento.

No dia 27 de janeiro de 2012, Sayed Kashua publicou sua crônica semanal sob o título "Por que aqui? Eu realmente quero que meus filhos cresçam num bairro judaico onde eu sou o único árabe?". Como de costume, ele introduz a temática exposta sob a forma de uma abertura em tom mais descritivo, quando a crônica aproxima-se do jornalismo: "Naquela manhã, depois de levar meus filhos à escola, ao invés de ir para o trabalho, eu voltei para casa para que assim pudesse acompanhar minha esposa e o bebê ao berçário pela primeira vez". O "eu do cronista" diz que preferiria que seu filho ficasse em casa, mas sua esposa estava ficando deprimida por ficar o dia todo com a criança e desejava voltar ao trabalho.

E então, ao chegarem ao carro, o "eu do cronista" nos conta que, ao prender a cadeirinha do bebê no assento traseiro, ele ouve um barulho estranho vindo do motor e, ao mesmo tempo, percebe que há um bilhete no seu para-brisa que dizia: "Por que aqui, dentre todos os lugares?". O "eu do cronista", então, esconde a nota de sua esposa, embora ela pergunte: "O que é isto?" [...]. “"Nada', respondi, tentando controlar o tremor no meu corpo. 'É apenas uma propaganda'.”

Nesta crônica, um tema ligado à vida privada faz a introdução. A ida ao jardim de infância parte da experiência particular. Levar o filho bebê ao jardim de infância não se restringe a um grupo social específico ou a uma problemática 
particular. Aqui, o árabe israelense é um cidadão qualquer, sem adjetivos nem especificidades. Mas, após a introdução, aquilo que era algo comum ganha outro enfoque, que levará o leitor a algo extremamente particular e único, que só poderia ser vivenciado dentro daqueles contexto e identidade particulares.

'Você está de mau humor?', ela pergunta. 'Não. Não estou de mau humor. Por que você diz que eu estou de mau humor?', ao que a esposa responde: 'Eu sei que você não gostaria que eu enviasse o bebê ao berçário, mas o que você quer de mim? O que eu deveria fazer? Vou ficar louca se continuar em casa, vou subir pelas paredes. Você não vê que é difícil para mim?'. 'Não tem nada a ver com isso', ele diz.

As questões privadas, relacionadas à decisão materna de colocar seu bebê num berçário e a dificuldade do casal de lidar com a questão, sentimentos comuns, misturam-se com a problemática social do árabe na sociedade israelense, tão específica que é. Nós, leitores de Sayed Kashua, sabemos que ele é um árabe que vive num bairro majoritariamente judaico e que este é um tema recorrente em suas crônicas. Mais uma vez, o cronista mistura um tema público e político com a vida privada e pessoal. O drama da mulher na vida privada (ser mãe/ trabalhar) vai andar em paralelo ao drama do eu do protagonista (ser árabe/ser israelense).

O eu do protagonista decide não partilhar a angústia provocada pelo bilhete no para-brisa.

Ficamos em silêncio até que chegamos ao berçário. Eu tirei a pesada cadeirinha do bebê e tentei sorrir para ele, passar a mensagem de que tudo estava bem, de que valia a pena viver. Tentei acreditar em todas as teorias que dizem que os berçários são bons; bons para o bom desenvolvimento social do bebê, para sua saúde física e mental. Tentei me convencer de que os bebês precisam 
ficar doentes para desenvolver sua imunidade, que os bebês estão predestinados a esta vida e que superarão os obstáculos, como o fato de ser abandonado pelos seus pais aos seis meses de idade, que fará dele uma pessoa mais saudável e melhor, especialmente psicologicamente.

Aqui, a preocupação de deixar o filho num berçário anda em paralelo ao obstáculo que o "eu do cronista" enfrenta como árabe na sociedade israelense. $\mathrm{O}$ árabe é considerado um doente na sociedade israelense? Que espécie de imunidade é esta que ele desenvolve? Quão desprotegido ele se sente numa maioria que o hostiliza? Frágil como um bebê, que se sente abandonado por sua família. Indefeso, desprotegido. Mas que sai desta experiência psicologicamente forte. $\mathrm{O}$ bilhete encontrado no para-brisa do carro faz com o que o eu do protagonista faça uma autoavaliação de suas decisões. O fato de ele ser um árabe numa maioria judaica e de ter decidido colocar seu filho num berçário judaico é revisto completa e rapidamente. A questão, que até então se restringia a um assunto particular e meramente privado - colocar ou não o bebê no berçário, onde morar -, tornou-se rapidamente um tema público e político.

\footnotetext{
'Por que aqui, dentre todos os lugares?'. Olhem para mim. Estou levando meu menino para um berçário perto de casa, judaico, uma amável cuidadora, mas judia; doces crianças, mas judias. Vão considerar meu filho diferente, um outro, aos seis meses de idade. De repente, isto me pareceu muito mais assustador e sério: 'Por que aqui, dentre todos os lugares?'
}

O "eu do cronista" decide levar o carro ao mecânico. "Parece-me que há um problema com a correia do carro", diz ao telefone o responsável pela companhia de seguro ao ouvir a descrição do barulho emitido pelo veículo. Mas o "eu do cronista" afirma: 
Sabotaram meu carro, eu sei. 'Por que aqui, dentre todos os lugares?'. Porque eu sou um idiota. Este é o motivo. Porque eu vivo numa ilusão. Porque eu acredito que se eu tiver bons vizinhos e meus filhos estudarem numa escola bilíngue, este será o reflexo do país. Mas não há razões para viver aqui, dentre todos os lugares, eu pensei, começando a me justificar para a pessoa que escreveu o bilhete.

O mecânico diz que a correia do carro havia se rompido. O leitor da crônica tem conhecimento do fato de que o "eu do cronista" possui um carro executivo quando o responsável pela companhia de seguro desculpa-se por não ter um veículo desta mesma categoria para oferecer ao cliente. Aqui, ficamos sabendo mais esta informação a respeito do "eu do cronista". Além de morar num bairro judaico, é bem-sucedido financeiramente a ponto de possuir um veículo luxuoso. O mecânico descarta a ideia de sabotagem e diz que o problema do carro foi causado por gatos, que entram nos veículos para se proteger do frio e estouram a correia.

O reflexo do país torna-se novamente um dos temas trabalhados nesta crônica, assim como na anterior. Como o reflexo do país se faz presente na postura de cada cidadão, seja ele judeu ou não judeu? Como viver como indivíduo, com suas dúvidas, questionamentos e hábitos, se há algo maior que ele, algo que o impulsiona a uma determinada atitude e comportamento? Como o reflexo do país poderia não influenciar o modo de ver o outro como indivíduo? Como o árabe poderia não se sentir sabotado ao morar numa vizinhança judaica? $\mathrm{O}$ fato de, no caso da primeira crônica, o árabe israelense também poder ser o consumidor do supermercado numa sexta-feira e, no caso da segunda, o árabe israelense morar num bairro judaico em Jerusalém ocidental - normalmente um bairro de classe média alta -, ter seus filhos em escola bilíngue e em um jardim de infância privado, o que denota uma população privilegiada de Israel, não diminuem a sensação de falta de ética e moral daquele país.

$\mathrm{Na}$ volta do jardim de infância, a esposa do eu do protagonista conta que o nenê chorou o tempo todo e que ela não o deixaria mais naquele lugar. Mas ele 
diz para sua esposa: "Nós precisamos nos mudar". "O quê?", ela disse. "O que você tem na sua cabeça?".

Contudo, o cronista volta a usar o humor quando a situação parece terrível. Os leitores usuais de Sayed Kashua já preveem o desfecho, mas nem por isso deixam de rir. Aliás, esta maneira já conhecida do cronista de caçoar com seu "eu do cronista" torna o cômico ainda mais engraçado. Quando estacionaram na frente do prédio na volta do jardim de infância, havia um outro carro estacionado no mesmo local onde estava o dele anteriormente. Lá também havia uma notinha presa no vidro da frente, escrita com a mesma grafia que a sua: "Por que aqui, dentre tantos outros lugares? Você está bloqueando o acesso às latas de lixo".

A anedota está completa. O "eu do cronista" não tinha sido "convidado" a repensar suas decisões e mudar-se para outro lugar. Não. Ele criou uma realidade outra, que o tornou desconfortável frente a suas decisões relativas à sua moradia na Israel judaica. Não foram os vizinhos judeus que sugeriram sua retirada.

O artifício utilizado pelo cronista para relatar ao seu leitor dúvidas e questionamentos que versam sobre a presença dos árabes israelenses na Israel judaica é o humor e a autoironia. É satirizando o sentimento de perseguição por parte do "eu do cronista" que ele vai encontrar um lugar para falar sobre inseguranças e dúvidas, sobre sua experiência na sociedade israelense judaica, que o recebe como um igual, por um lado, mas que mesmo que inconscientemente, faz com que este cidadão sinta-se alvo de preconceito e racismo, mesmo quando, na relação interpessoal, não seja isto o que aconteça.

A ida ao jardim de infância é o mote, na segunda crônica, para expor a condição do árabe na sociedade israelense. Mas isto é feito de maneira satírica, artifício que dissimula o enfrentamento com a condição inferior do árabe na sociedade israelense. Por este motivo, o caminho que o cronista faz é dúbio. Ele expõe os profundos dilemas pelos quais passa o cidadão árabe israelense onde morar, o que fazer quando é alvo de preconceito, como criar seus filhos -, mas ele trata do tema de maneira extremamente sutil, pois o reveste de sátira.

Em ambas as crônicas, na do supermercado e na do bilhete no carro, o "eu do cronista" sente-se enganado e humilhado porque não consegue perceber os códigos daquela sociedade. Em Israel, o árabe israelense vive num bairro judaico. Ele pode ser o consumidor do supermercado numa sexta-feira de corre- 
ria, ele pode não ser discriminado devido à sua origem étnica. Esta é a mesma Israel que aprova leis que expulsam refugiados sudaneses e que quer manter "o caráter da nação". O mesmo país que não é nem crítico nem igualitário, por um lado, é democrático o suficiente para publicar uma coluna satírica escrita por um cidadão árabe israelense, que sugere que o árabe não é maduro o suficiente para viver as complexidades daquela sociedade.

Em seu primeiro romance Árabes Dançantes (2002), há uma passagem em que o protagonista afirma que os árabes preferem ser cidadãos de sétima categoria a serem escravos de seu próprio povo.

Um árabe bravo, como ele descreve seu filho no colo da esposa no início da crônica aqui analisada. É assim que estes "eu do cronista” vivem. A culpa e sentimentos de insegurança estão presentes neles. No caso da primeira crônica analisada, por não ser um dos árabes que trabalha no supermercado, um Walid qualquer, funcionário do setor de limpeza do supermercado. Também no caso da segunda crônica, a culpa de ter um carro de luxo, a insegurança de morar num bairro judaico de Jerusalém, o faz sentir-se alvo de preconceito. Estes "eu do cronista" sentem-se enganados e perseguidos pelos judeus à sua volta, mesmo quando estes não necessariamente os estão expulsando, ao menos no nível pessoal. Pois no nível pessoal, eles são muito bem-sucedidos e não são alvo de preconceito.

Se em ambos os casos o "eu do cronista" demonstra ser uma pessoa extremamente infantil, há um outro lado das crônicas que demonstra um lado muito maduro, mas desta vez do cronista, e não do "eu do cronista". O uso maduro da ironia e do riso, da autocrítica e humor próprio para mostrar os dilemas e ambiguidades do "eu do cronista", acontece de maneira explícita e consciente, embora no texto literário ele apareça de maneira inconsciente e imatura. Seus profundos dilemas, seus conflitos ideológicos e identitários aparecem e desaparecem na dupla face da crônica, que se constitui num ambiente camuflado entre o divertir e o criticar, entre o útil e o fútil, entre a literatura e o jornalismo, entre o que é privado e o que é público, entre o que é o indivíduo e o que é a sociedade. Entre o que é preconceito e o que é culpa, entre seus pais e seu país.

A dualidade do Estado de Israel se faz presente nestas crônicas. Ela penetra em seus personagens, em suas atitudes, em suas dúvidas e em suas emoções. Entre a Israel idealizada por Herzl e a Israel dos antidemocratas e antissionis- 
tas, nas palavras de Avineri, ainda existe uma possibilidade cuja voz é ouvida em tom satírico semanalmente por aqueles que a querem escutar.

\section{Referências}

AVINERI, Shlomo. Rereading Herzl's Old-New Land. Acesso em: 20 ago. 2012. Disponível em: $<$ http://www.jewishreviewofbooks.com/publications/detail/rereading-herzls-old-new-land>

ARRIGUCCI, Davi Jr. Enigma e Comentário - Ensaios sobre Literatura e Experiência. São Paulo: Companhia das Letras, 2001.

CANDIDO, Antonio et al. A Crônica - o gênero, sua fixação e suas transformações no Brasil. Campinas, SP: Ed. UNICAMP; Rio de Janeiro: Fundação Casa de Rui Barbosa, 1992.

KASHUA, Sayed. Aravim Rokdim. Tel Aviv: Modan, 2002. (Árabes Dançantes) . Vaiehi Boker [Fez-se a manhã]. Jerusalém: Keter, 2004. . Guf Sheni Iachid. Jerusalém: Keter, 2010 (Segunda Pessoa do Singular). . Medina im ofi - Peguisha im hassatan bassuper - iom shishi - 13 lachodesh. Haaretz, Israel, 20 jan. 2012. Acesso em: 4 abr. 2012. Disponível em: <http://www.haaretz.co.il/ magazine/sayed/1.1620437> (Um país de caráter: um encontro com o demônio no supermercado numa sexta-feira 13)

. Lama davka kan - Haim beemet ani rotse legadel et ieladai beshchuna iehudit sheba ani haaravi haiachid? Haaretz, Israel, 27 jan. 2012. Acesso em: 7 ago. 2012. Disponível em: $<$ http://www.haaretz.co.il/magazine/sayed/1.1625664> (Por que aqui? Eu realmente quero que meus filhos cresçam num bairro judaico onde eu sou o único árabe?)

OLIVEIRA, Maria Rosa Duarte de. A crônica machadiana entre o jornal e o livro. In: BERRINI, Beatriz (org.). Eça \& Machado - Simpósio Internacional PUC-SP/UNICAMP. São Paulo: EDUC, Fapesp, Fundação Gulbenkian, 2005, p.225-240.

. O cronista ilustrado e o burro-filósofo. Revista da ANPOLL. Machado de Assis e Guimarães Rosa aspectos linguísticos e literários, v. 2, n. 24, p. 31-45, jan.jul. 2008.

SIMON, Luiz Carlos. Duas ou três páginas despretensiosas - a crônica, Rubem Braga e outros Cronistas. Londrina: Eduel, 2011.

SMOOHA, Sammy. Arabs and Jews in Israel: Conflicting and Shared Attitudes in a Divided Society. Boulder: Westview Press, 1989. vol. 1. . Arabs and Jews in Israel: Change and Continuity in Mutual Intolerance. Boulder and London: Westview Press, 1992. vol. 2 . Ethnic Democracy: Israel as an Archetype. Israel Studies. v. 2, p. 198-241, 1997.

WEILER-POLAK, Dana; ZARCHIN, Tomer. Israel begins deportation of South Sudanese migrants. Haaretz, Israel, 10 jun. 2012. Acesso em: 7 ago. 2012. Disponível em: <http:// www.haaretz.com/news/national/israel-begins-deportation-of-south-sudanese-migrants$1.435523>$ 